TITLE: Taxing the Indigenous: A History of Barriers to Fiscal Inclusion in the Bolivian Highlands

History and Anthropology doi.org/10.1080/02757206.2017.1281266

AUTHOR: Miranda Sheild Johansson

Department of Anthropology, University College London

This work was supported by the Economic and Social Research Council [grant number PTA-0302006-00299]. 


\section{TITLE: Taxing the Indigenous: A History of Barriers to Fiscal Inclusion in the Bolivian Highlands}

ABSTRACT Following the electoral success of left wing and pro-indigenous President Evo Morales, the indigenous poor in Bolivia find themselves at the centre of a new vision of the state, echoed by a fervent citizenship project to include them as contributing participants in this new Bolivia. The state is working to initiate these hitherto informally employed subjects into an individualised fiscal regime: to make them into "taxpayers." While the highland indigenous population have supported Morales' political project, they resist inclusion into the broader statesponsored project. This is not simply about avoiding financial obligations; their resistance is instead firmly rooted in the historical experience of fiscal exploitation, general suspicion of any state-run scheme as well as a clash of exchange models. I argue that in order to overcome these barriers, the Tax Office has to succeed in separating fiscal expansion from its association with an abstract state concept, and instead link it to palpable everyday life and politics, such as the union structure and Morales' project of indigenous inclusion.

KEY WORDS taxation, Andes, state, unions, citizenship

One Sunday in late June 2008, the highland village of Bolívar of ayllu Kirkiyawi, in the Bolivian department of Cochabamba, was busy preparing for a grand titling ceremony. The Instituto Nacional Reforma Agraria (INRA, National Institute of Agrarian Reform) had arrived to award the area the legal personality of an ayllu (an Andean indigenous kin-territorial unit) which meant that their status of Tierra Comunitaria de Origen (TCO, Native Community Lands) would be upgraded to ensure total rights over land and subsoil resources in the ayllu. ${ }^{1}$ It took INRA five long years to complete their investigation into the eligibility of the area for ayllu status, having spent considerable time examining colonial documents, interviewing inhabitants and assessing borders with neighboring communities. As an ayllu, Kirkiyawi had to prove its presence in the area from "time immemorial" and demonstrate that the present way of life could be identified as traditional ayllu culture.

Fulfilling these specific criteria are a condition of state recognition, which is in turn necessary for indigenous communities that wish to consolidate political power in contemporary

\footnotetext{
${ }^{1}$ In a TCO the community owns the land, in this case land is owned by the whole ayllu. No individual may sell any land within the TCO or speculate on it. While a majority of land in Bolívar received the TCO title from INRA, two sections (cantones), Comuna and Challoma, did not. Because these are ex-hacienda areas, their population received private land titles following agrarian reform in 1953. As they already had land deeds they decided to opt out of the TCO. Private land deeds allow people to do what they wish with their land, although sub-soil resources are not protected.
} 
society. The criteria themselves are problematic, generated by a narrow 'ayllu concept' which is part reality, part construct mobilized by indigenous groups themselves for the benefit of a wider national and international audience of NGOs and government institutions, and part fantasy conjured up by this same audience (Albro 2006). Largely due to the work of indigenous activist the ayllu has become a readily available and significantly mass-mediated cultural heritage resource (Albro 2006, 401). Kirkiyawi's existence from "time immemorial" was straightforwardly evidenced by documents kept by the ayllu authorities that date as far back as the seventeenth century. They show the ancestral line of their ayllu leader (the cacique), the historical presence of ayllu Kirkiyawi, and its dealings with the colonial state and Catholic Church over several hundred years. However, the process of determining whether the latter criterion of traditional ayllu culture, was fulfilled is far more opaque.

On a stage decorated with locally-made weavings, a stamped and signed document was handed over to the senior ayllu authorities: the cacique, Don Vicente Arias, and the ten kuraj tatas. ${ }^{2}$ That evening, many of the participants in the ceremony gathered in one of the village's small guesthouses where homemade maize beer, chicha, and bottled lager was being sold and consumed. The atmosphere was thoughtful rather than celebratory. Speaking with one of the kuraj tatas, I asked him if they were happy with how the day had gone, suggesting that they must be very pleased that after all these years INRA had given them ayllu status and they now had the documents to prove it. "It is good," he said, "It is what we need to protect our land." However, these words were spoken with a clear lack of enthusiasm so I pushed him further, asking if he was not satisfied with the outcome. "Well, the thing is, now that the land is ours they can come and ask us for tax. Before the land belonged to no one - so who would they tax? - but now they have papers and the papers say the land is ours." Assigning ownership also assigns liability and responsibility (cf Sikor 2006; Verdery 2004), as this kuraj tata was well aware. Throughout my time in ayllu Kirkiyawi I heard many speak with fear and suspicion of their potential future relationship with the state. The more cynical argued that the very purpose of the process of re-titling land, saneamiento, was to enable the government to lay the foundation for comprehensive fiscal expansion. While unable and unwilling to reject the security and rights over land that an ayllu title conferred, these authorities did not rejoice in their success, but rather treaded carefully into what they perceived to be a minefield of unknowns, hoping nothing would blow up in their faces.

Since the Agrarian reform law in 1953, which abolished the previous tributary system, the majority of the rural indigenous population in Bolivia pays little or no tax. In recent history there have been no attempts to tax ayllu or TCO lands, although the integrity of the TCOs have been challenged; a famous example being the TIPNIS (Territorio Indigena y Parque Nacional Isiboro Secure) conflict where the local population is resisting the building of a highway through their

\footnotetext{
${ }^{2}$ The cacique is the top ayllu position in Kirkiyawi. Below the cacique sits two kuraj tatas, one for the Aransaya (highland) and one for the Urinsaya (lowland). There are an additional eight kuraj tatas, one per jap' $i$ (territorial sub-division of the ayllu). Below the kuraj tatas are the jilanqus, each representing a village. At the beginning of every new year in early January, there is a rotation of roles. A new jilanqu is appointed in every village and a new kuraj tata for every jap'i.
} 
TCO lands (see Fabricant and Postero 2015). ${ }^{3}$ In urban areas the poorer classes, made up of people who both self-identify as indigenous and those who do not, to a large degree make their livings in the informal market and pay no national tax. Many of these workers are migrants: temporary, seasonal and/or permanent migrants from areas like ayllu Kirkiyawi. The non-contributory status of Bolivia's lower classes, and particularly indigenous groups, is a problem for the left leaning, pro-indigenous MAS government (Movimiento Al Socialismo, Movement For Socialism) as the highland, indigenous citizen is crucial to President Evo Morales' vision for Bolivia. Of Aymaraspeaking descent and keen to emphasise his indigenous credentials (Albro 2006), Morales has built his presidency on this highland identity coupled with his background as a formidable union leader of the coca growers. He has successfully summoned up a devoted electorate through a project that claims to be one of inclusion, bringing the previously exploited and excluded "indian" to the centre of the state-making project and attempting a syncretism of trade unionism, populism and indigenous democratic practices (Lazar 2008, 174). ${ }^{4}$ Through the introduction of universal benefits, simplified tax rules and campaigns depicting tax as a moral good, the government now hopes to encourage Bolivia's indigenous poor to enter into a social contract with the state and in so doing become fully fledged citizens. While many indigenous groups welcome the promise of inclusion, the state's call to its people to fulfill their tax obligations echoes through a complex moral landscape.

Historically, taxation of the indigenous poor was built upon a relationship of exploitation rather than inclusion, solidarity or equality. Since the sixteenth century onwards, the rural poor carried the heaviest tax burden in the country (Platt 1982a). Memories of this centuries-old fiscal exploitation and persistent state corruption have resulted in a deficit in confidence in the state. John McNeish shows that this scepticism towards state-sponsored projects is widespread throughout the region, and not just confined to Kirkiyawi (2001). In ayllu Santuario de Quillacas, he describes how processes of participatory development and decentralisation failed partly due to the high levels of apathy and suspicion with which people approached new government legislation. In addition to these conditions of distrust, the government is also challenged by the need for new models of citizenship, where the imagined collective is national as opposed to local, in order to create consenting taxpayers. As Lazar demonstrates, citizenship in the migrant town of El Alto is based on participation in a range of collectivist organisations rather than the individual's unmediated relationship with the state (2008). The same holds true for many of the migrant towns and suburbs in Bolivia. As well as this more recent type of local citizenship, I argue that the particular way in which fiscal exploitation was organised in the past, with ayllu leaders as tax

${ }^{3}$ TIPNIS conflict: The plan to build a road through a TCO against the wishes of the local inhabitants sparked big marches and violent crackdowns by the police in 2011. While the road building was paused following the government's mishandling of the protests, it has in the last year been given the green light again, thus undermining the legal power of the TCO.

${ }^{4}$ Despite the fact that it is a derogatory term that is both unspecific and homogenising, I use the term "indian," as it is effective in referring to a large subaltern group which can be bracketed off as a collective due to its shared marginality (cf Canessa 2005; Harris 1995b; Weismantel 2001). Following Canessa (2005) I do not capitalise the "i" in indian as people are not nationals of India and the term is analogous to creole or mestizo, neither of which are normally capitalised. 
collectors, created a local collective, rather than a national one. Given this "de-centralised" form of citizenship, it is not strange that a tax regime rooted in an abstract sense of individual obligations to a distrusted state struggles to convince the indigenous population of its virtues.

This article will discuss the current attempts of, and barriers to, fiscal expansion in Bolivia by offering an historical perspective on the relationship between taxation and the highland indigenous population. After an initial section on the present government's attempts to incorporate its indigenous population into the fiscal system, the article will investigate the historical experience of tax in ayllu Kirkiyawi. In order to do this, I bring both archival and ethnographic evidence into conversation with the regional literature, producing a multi-layered and detailed sketch that illustrates a highland community's fiscal history. While the overwhelming character of historical fiscal engagement of indigenous peoples has been exploitative, the present analysis argues that there is potential to overcome these barriers to fiscal expansion amongst the indigenous population. The willingness on behalf of the indigenous population to regularly pay dues to urban and rural unions as well as cooperatives demonstrates their ability to imagine a larger abstract collective as well as preparedness to contribute to this financially. Therefore, to succeed in turning the indigenous population into tax-payers the government needs to disassociate fiscal expansion from the state, and instead present the fiscal project as something more akin to a social movement or union project.

\section{Tus Impuestos, Tu País - Your Taxes, Your Country}

Since Evo Morales' first electoral victory in 2005, the relationship between Bolivia's indigenous poor and the state has been radically altered. Prior to the early 2000s, this group tended to inhabit state margins, but in the last ten years it has shifted to the heart of the state-making project (Albro 2005; Canessa 2006; Dunkerley 2007). The background and social status of the indigenous poor now confer legitimacy to their citizenship that other groups struggle to attain. For the first time they have also become beneficiaries of the state as a new pension scheme and inschool grants have been rolled out. However, despite this central location in a project putatively built on indigenous notions of solidarity and equal exchange, they remain largely outside the state's own main mode of exchange - tax. In an attempt to remedy this, the Bolivian Tax Office, Impuestos Nacionales, are currently engaged in a multi-pronged strategy aimed at increasing the percentage of tax-paying citizens in the country. Employing a mix of administrative simplification, threats and punitive measures with an appeal to a sense of moral obligation and offering a vision of an inclusive future, they aim to shift people from the informal to the formal economy.

Régimen Tributario Simplificado is a simplified tax regime for market vendors, craftsmen and small business owners. It attempts to bring people working in these sectors into the formal economy through a scheme presented as advantageous and well adapted to the needs of the these vocational groups. The government's desire to expand the tax-paying population and its ability to sanction those who do not pay is increasingly visible to the public. Information about Régimen 
Tributario Simplificado and messages regarding the importance of issuing and demanding facturas (receipts), with every transaction, is being advertised through various media outlets, including television. In addition, the local population in Cochabamba report a rise in spot checks on small businesses by the Tax Office. Since December 2015 the Tax Office have also increased fines for tax evasion.

The appeal to a moral obligation is a wide campaign using a range of tactics. With the strap line "Tus Impuestos, Tu Pais" - "Your taxes, your country" - the Tax Office hope to change the realities and strongly held beliefs about who pays and who benefits in the fiscal system. On the Tax Office website it states that the vision of the institution is to help contribute to an improved quality of life for all Bolivians in order to vivir bien, live well. Vivir bien is a politicised term that is meant to evoke a purportedly indigenous approach to life, a philosophy presented as one of respect for fellow humans and mother earth, pachamama. While the phrase is a recent creation of Aymara indigenous intellectuals, rather than part of indigenous everyday culture, it belongs to the language of the indigenous rights movement and as such the adoption of it by the tax office works to create a national project inclusive of indigenous social movements (Spedding 2010). ${ }^{5}$ In explicitly linking tax-paying to the realisation of vivir bien, the government is working to imbue taxation with a specific kind of morality, an ostensibly indigenous morality. Within this narrative, they are also depicting indigenous groups as intrinsically suited to paying tax, as they are presented as "naturally" better at vivir bien than their non-indigenous countrymen (Gudynas 2011). In so doing, they conjure a connection between taxation and the shared responsibilities of a collective community; by referencing vivir bien and pushing the Régimen Tributario Simplificado, the government is creating a vision of such a collective,

One of the Tax Office's most important aims is to create a culture of willing tax payment. They even have an official program designed to implement this, explicitly called Creando Cultura Tributaria. This programme works in two ways: Firstly, through education targeted to primary schools, with information leaflets about Cultura Tributaria and its importance to citizenship. The cartoon characters of Don Fisco, and the cheeky monkey mono Titi, a tax evader, explain the virtues of paying tax to children and their parents. Secondly, the programme has recently created the Día de la Cultura Tributaria. First held in 2013, the annual event takes place every September in the main squares of all major cities. Billed as a day of fun activities for the family, it communicates messages regarding fiscal responsibility, while promoting a positive feeling around fiscal inclusion.

The introduction of benefits for those on low incomes - The Bono Juancito Pinto (inschool grant of 200 bolivianos, circa $£ 23$, a year for school children between year one and six) and Renta Dignidad (old age benefit of a 200-250 bolivianos, circa $£ 23-£ 29$, monthly payment for those on low incomes over the age of sixty) are non-contributory benefits that were instituted in 2006 and 2008 respectively. ${ }^{6}$ These payments, the latter of which has a real financial impact on

\footnotetext{
${ }^{5}$ The indigenous Aymara-speaking people are a highland group. They make up one of the largest indigenous groups in Bolivia and are a strong political force in the country.

${ }^{6}$ The domestic GDP in Bolivia in 2015 was $£ 1941$. With the rural poor earning significantly less than this average the
} 
the lives of the indigenous poor, work to ensure that this group experience inclusion in, and benefits from, the state project. By extending them, the state has opened up a new level of exchange, and they aim to build trust in the value of paying into a state run system. Despite the rhetoric of reciprocity and support through fiscal responsibility, it is widely known and often publicly stated by the government that both kinds of benefits have been funded through the nationalisation of Bolivia's hydrocarbon industry. Indeed, the return of oil and gas to state ownership and increased taxes on foreign companies are some of the main reasons for Evo Morales' continued support. "Bolivian resources for Bolivian people" is a powerful message, precisely because previous fiscal exploitation was regularly tied up in resource extraction whose profit was only enjoyed by a small national elite or expatriates (Sieder 2002). While channelling profits from the hydrocarbon industry into welfare programmes is popular in the short-term, one of the long-term challenges for the government is to move away from rentist economics and resource dependencies, and create a link between tax and the public good, a link that overrides the previous dynamics associated with private subsidy.

During his time in office, Morales has been presented as an anti-establishment character who is working to promote deep change. His flagship programme, Bolivia Cambia, Evo Cumple (Bolivia Changes, Evo Fulfils), sets him out as the driving force in a move away from the status quo and earlier elitist governments. The rural and urban poor have placed much faith in this move. In the last few years, Morales' popularity has been increasingly undermined by a series of corruption scandals, as well as unpopular political decisions, including a resource extraction programme that undermines the territorial and cultural rights of indigenous groups (Bebbington 2009; Kaup 2010). In addition to a growing opposition in the media luna, ${ }^{7}$ an area characterised by staunch anti-Morales sentiment, the government has also lost significant support in urban areas, amongst middle class voters, as well as amongst activists. This includes indigenous, left-leaning groups who now view his election promises as cheap indigenous and ecological rhetoric (Gustafson 2013). Despite his current waning in popularity, Evo Morales retains significant support amongst the voters and has managed to successfully present himself and his programme as anti-establishment and even (at least during his first few years in government) as a political being that somehow transcended the state (cf Goudsmit 2006). Whilst the inclusion into a new pluri-national Bolivia has been welcomed by many indigenous groups, and electoral commitment to Evo Morales and MAS was strong during his first two terms (2006-2009, 2009-2014), a long and complex relationship between rural indigenous taxpayers and the state in Bolivia has been and continues to be a serious hurdle in the project of forging a nation of moral taxpayers. In the next section, I investigate the structure and history of ayllu Kirkiyawi, in order to draw out some of the deep-seated barriers amongst the indigenous highland population towards fiscal inclusion.

Renta Dignidad represents a considerable boost in income.

${ }^{7}$ Made up of the departments of Santa Cruz, Beni, Pando and Tarija. The four departments create a crescent shape to the east of the country, hence its name media luna (half moon). 
Since the fall of the Aymara Kingdoms of a thousand years ago, the history of the Bolivian ayllu can be understood as a movement towards fragmentation (Molinié Fioravanti 1986; Murra, Revel and Wachtel 1986). Whilst the Aymara kingdoms were great administrative units with intricate and powerful political structures (Bouysse-Cassagne, Harris, and Platt 2004; Espinoza Soriano 1997; Murra, Revel and Wachtel 1986; Molinié Fioravanti 1986), the present day ayllu is highly localised and centred on subsistence and intimate relationships with the immediate landscape (Arnold 1988 Goodale 2001). We know that the ayllu existed as a socio-economic institution amongst the Aymara speaking highlanders during the period of the Tiwanaku Empire in the seventh to the twelfth century AD. ${ }^{8}$ The power of the empire drastically diminished around the time of the first millennium, possibly due to successive years of drought (Klein 2003). In the centuries that followed, the Aymara kingdoms gained political strength and battled each other for control over land, water and people (Silverblatt 1988; Murra 1978; Stern 1982; Rostworowski 1978). In the southern altiplano around Kirkiyawi, documentary evidence cites seven Aymara kingdoms: Charka, Qaraqara, Sura, Quillaca, Caranga, Chui and Chicha (Bouysse-Cassagne, Harris and Platt 2004). The Incas and the Spanish colonists referred to them collectively as the Charka federation, or the seven nations of Charka, and later when comprising a colonial administrative unit, the wider highland area was known as the Audiencia de Charkas. The incorporation of the Aymara kingdoms into the Inca Empire (Tawantinsuyu) was the beginning of large-scale fiscal engagement for the highland population, an activity that would be sustained for hundreds of years to come. ${ }^{9}$

In tribute to the Incas, the Charka confederation supplied soldiers for the empire, and the Aymara section of the Inca army were renowned for being great and fearsome warriors. Labour was also sent to the Cochabamba (then called Qucha Pampa) valley where maize was grown; this seasonal migration of the mittayoc (agricultural labourers bound by tribute) to work the lands in the valley and feed the empire, created the largest migratory flow in Tawantinsuyu. The administrative machine and greater needs of Tawantinsuyu, demanded that the Charka federation adopt a position of servitude, and so a process of resettlement and reordering of Charka people and communities was initiated (Bouysse-Cassagne, Harris and Platt 2004). The Sura, who had direct access to valley lands in the temperate Cochabamba, were resettled to these lowlands as part of the mita (Espinoza Soriano 1997; Mercedes del Rio 2005). As soldiers in the Inca army or workers in the maize fields, the altiplano population bore a heavy fiscal burden (Larson 1998). While the history of tribute payments to the Incas is not discussed in ayllu Kirkiyawi as an experience of

\footnotetext{
${ }^{8}$ The centre of the Tiwanaku empire, the now archaeological site of Tiwanaku, is close to lake Titicaca and at its height the empire incorporated much of present-day Bolivia, Peru and Chile. It was at its strongest between 500AD and 1000AD.

${ }^{9}$ In the language of the Inca, Quechua, the name of the empire is Tawantinsuyu (literally, four corners). The empire began taking shape in Cuzco, Peru, in the beginnings of the thirteenth century. In one century the empire had expanded into Ecuador, Columbia, Bolivia, Argentina and Chile. Though huge, the empire was short-lived and fell with the invasion of the Spanish. In 1533 the last Sapa Inca (hereditary position of ruler, perceived as divine), Atahuallpa, was killed, and by 1572 the last strongholds of the Incas had been completely conquered.
} 
exploitation, these first mitas (systems of labour tribute), and in particular the obligation to supply labour in the maize fields, lay the foundations for the later colonial mita and forced labour in the mines (Larson 1998), something which is most certainly remembered as oppressive.

Ayllu Sura Qurpa Kirkiyawi, the full historical name of Ayllu Kirkiyawi, was part of the Charka federation. Evidence collected by the Bolívar municipal office and by the indigenous rights organisation CONAMAQ concludes that Kirkiyawi was part of the kingdom of Sura. ${ }^{10}$ However, Izko (1992) suggests that, in consideration of documentary evidence pertaining to border disputes in the area, the Turpa, the ethnic group living in Kirkiyawi, in fact comprised an independent kingdom, squeezed in between the larger kingdoms of Charka and Sura. According to Izko, Kirkiyawi belonged to neither nation, though it did form alliances with both (Izko 1992, 21). Kirkiyawi is mentioned several times in the 1646 third colonial Revisita of the Charka federation under the viceroy Garcia de Mendoza, executed by el Juez Visitador de Tierras Don Jose de la Vega Alvarado. The documents recognise the existence of ayllu Kirkiyawi as an originario community dating back to Inca times, but do not indicate whether the gran ayllu was an independent kingdom or part of either Charka or Sura (Atlas de Los Ayllus Sura y Qurpa Kirkiyawi 2002). ${ }^{11}$

In 1538 the Charka federation was subjugated by the Spanish conquistadores Gonzales and Hernando Pizarro, brothers of Francisco Pizarro, who invaded what is now Peru and Bolivia on behalf of King Charles I of Castille. Having seized power from the Incas, the brothers defeated the Aymara lords, marking the beginning of European domination over the lands and people. As a result of the European invasion, local polities were further weakened (Espinoza Soriano 1997). However, the ayllu did continue as a basic organising unit and the Aymara groups consolidated at the level of the moiety or minor ayllu. Some were able to recreate previous structures of internal exchange with the lands that were still available to them along with new lands that other groups had lost, while others diminished in size (Murra, Revel and Wachtel 1986).

Colonial fiscal authorities employed ayllu leaders, caciques, to act in the role of local tax collectors. By using indigenous leaders for the purpose of tax collection, distance with the state was maintained. The role of the ayllu authorities in tax collection and the processes and rules by which individual ayllu members could come to inhabit these posts, are both important components to the historical barriers of fiscal inclusion.

Political and religious authority within ayllu communities today is generally organised through a hierarchical system of cargos. Cargos are unpaid positions of responsibility and decision-making that rotate between all (usually male) adult inhabitants of an ayllu. It is a system that ensures the cost and burden of leadership is shared between community members, it also

10 Consejo Nacional de Ayllus y Markas del Qullasuyu (CONAMAQ). Bolivian highland Indigenous Rights Organisation that ultimately want to see the re-establishment of the gran ayllus and total de-colonisation.

${ }^{11}$ According to the Atlas de los Ayllus Sura y Qurpa Kirkiyawi the petition was signed by the then cacique of Kirkiyawi Don Juan Domingo Fernández Mamani. However, Izko (1992) in his examination of the same document claims that the signatory on behalf of Kirkiyawi was a cacique by the name Juan Pedro Mamani. Whether these two people are in fact one and the same, whether there were two acting caciques, one for the aransaya and one for the urinsaya, during this time in Kirkiyawi or whether one of them was not a cacique but held another ayllu position, is unclear from the evidence. 
arguably distributes power and fosters unity as well as cultural distinctiveness (Goodale 2001; McNeish 2001; Rasnake 1988). The cargo system is part of what Harris has called the ethnic economy (1995a, 2000), and in theory it ensures a democratic approach to work, land and power (Rivera 1990). Amongst other things, it is the moral underpinnings of the idealised cargo system, a key aspect of the ayllu as a "cultural resource", which now has the potential to clash with a regime of individualised taxation. Due to the crucial role of the cargo system in the presentation of the ayllu as a profoundly democratic organisation that can provide a blueprint for an alternative form of politics, its provenance, historical development, as well as current practice has been much discussed by activists and anthropologists alike. Abercrombie (1991) describes how the contemporary cargo system was created through an interplay of Spanish religious collectives, cofradias (confraternities), where the sponsorship of religious festivities were organised on a basis of taking turns, and the institution of rotational posts within colonial town councils (Abercrombie 1991; Celestino and Meyers 1981; Christian 1981;). By the mid-eighteenth century, these civil and ecclesiastical obligations merged into a single system - the fiesta-cargo system (Abercrombie 1991, 106). Both Platt (1987) and Arnold with Yapita (2006) argue that whilst the cargo system solidified during the colonial years, traditions of "passing turns" pre-dated the Spanish invasion and were bound up in inter-ayllu and Inca battles over land and its resulting circulation. This lends some support to the claim, often made by Bolivian indigenous rights movements, that the panLatin American cargo system is originally an indigenous custom. But ayllus are not the only indigenous organisations on the continent that practise a cargo system and present it as a unique marker of their indigeneity, and some writers (for instance, Sánchez 1982) argue that the notion of reciprocity and egalitarianism in the Andean ayllu is simply a fantasy of equal exchange and egalitarianism. Neither have ayllus always practiced a system of rotational leadership (CañedoArgüelles and Gutiérrez Flores 2005). Indeed, ayllu leadership structures and the wider cargo system have historically combined hereditary, meritocratic and elective (taking turns) systems. As Bolivian Historian, María Luisa Soux explains, within the ayllus hereditary and rotational leadership ran in parallel for centuries after the Spanish invasion and there was a considerable degree of variety between the local authority structures, meaning a term like cacique in fact obscures a series of different hierarchal positions (Soux 2010, 224). The move towards majority rotational posts in ayllus happened over time and was sparked by several factors, including the influence of the Borbonic reforms in the eighteenth century and the passing of administration of territories to the Audiencia al Virreinato del Rio de la Plata, as well as pressure from below which questioned cacique power (Thomson 2002).

The Turpas, the ethnic group of ayllu Kirkiyawi, Izko claims, are something of a mystery, and though Kirkiyawi features at times in historical documents, information is sparse (1992). Despite the paucity of data, we can be fairly sure that the Turpa lived in what is now Kirkiyawi and were probably governed by a cacique belonging to the same line as the present cacique, Vicente Arias and his uncle Marcos Mamani. ${ }^{12}$ Whilst most other ayllus have by now done away ${ }^{12}$ According to people in Kirkiyawi now, the previous cacique, Don Marcos Mamani, can be directly traced back to
the earliest rulers, including whoever signed the Third Revisita. The genealogy of the present Cacique can then be 
with their hereditary lords, Kirkiyawi is unusual in its authority structure as the role of the cacique, the head of the ayllu, remains hereditary, and is thus not accessible to every man in the ayllu.

The continued presence of a hereditary position in Kirkiyawi to this day does evidence an acceptance of what is now considered to be atypical ayllu traditions. In Kirkiyawi, Cacique Vicente Arias was not viewed as an illegitimate leader; rather he was spoken of with a mixture of disinterest or a vague sense of pride. As he was not a formidable politician, and the post itself currently lacks in any real clout, many of his actions had very little impact on the lives of the locals. However, people did express a sense of pride in the fact that claims to land could be made as a result of his being a descendent of a previous Aymara lord, someone who was imagined to be more impressive than Vicente Arias himself. The fact that the present cacique is a blood relative of the signatory of the ancestral papers in his keeping - papers which at one point were crucial to safeguarding the ayllu lands and are still considered to be the most effective protection against any future infringement of their lands - is said to lend an added layer of authority to the documents. The unusual case of Kirkyawi's hereditary system is an important example of the multiplicity of ayllu historical realities, but it also serves to remind us of the shifting moralities and structures within the ayllu over time.

Ayllu notions of exchange and governance may be less wedded to a democratic model than it appears to be when presented part of a 'cultural resource' (Albro 2006), but despite the clear historical variety of cargo systems and leadership structures, tax collection was characterised by a handful of features which are markedly different from national tax collection today. These features are: local collection with the collector being an individual of power within the community, communal payment of the tribute, and the exchange of tax for rights to land, all this contrasts the current fiscal system which is centrally organised, demands payments by individuals and does this in exchange for abstract societal benefits.

Returning to the national history of taxation - relations between the Bolivian ayllus and colonial and republican governments have been characterised by the state's fiscal reliance on the rural population's contributions, while at the same time numerous factors made the collection of contributions problematic; among them the state's desire to eradicate uncivilised indians, and the rural populations' efforts to remain out of the state's reach, including their overt attempts at resistance and revolt. Starting with the Spanish invasion in 1532 and the crushing of the Inca Empire, the colonial state's reconfiguring of the ayllu, both intentional and otherwise, was a constant throughout the period. In 1572 the colonial government, under the administration of Viceroy Toledo, ordered massive resettlements into reducciones, literally "reductions," or new towns. In the reducciones land and people were reorganised to maximise agricultural potential, enable bonded labour, and facilitate the running of a tributary tax system skewed towards the

traced back to at least 1646, when colonial documents show the signature of Cacique Juan Domingo Fernández Mamani. In Kirkiyawi, some people were able to cite the names of the caciques going back three generations Don Marcos Mamani, his father Don Nicanor Mamani Ibarra and his grandfather Don Mariano Mamani. The present cacique, Vicente Arias, is the nephew of Don Marcos Mamani. The position passed to him when Don Marcos died leaving no male heirs. Don Vicente sometimes goes by the name of Mamani in order to associate himself with the legitimate line of the caciques of Kirkiyawi. 
extraction of wealth from the rural indigenous. The creation of these reducciones concentrated indigenous populations into villages or small towns, and broke up existing hierarchies and networks. Sample studies indicate that huge numbers of people were resettled - one example describes how 900 communities, involving 129,000 people were reduced to just forty-four reducciones (Klein 2003).

Toledo also moved to intensify the already established mita system, that was utilised by the colonial government to provide labour for mines across the altiplano, most famously at the silver town of Potosí with its Cerro Rico - the richest silver mine in the whole world in the mid-sixteenth century (Murra, Revel and Wachtel 1986, 7). The colonial mita demanded that one seventh of a community's male originario population (those living with their original kin group and who have rights and responsibilities to the land they work) should at any time be working in the mines for little compensation. This resulted in constant movement between the mines and the villages, not just of the men themselves, but also of their families who regularly travelled to the mines with provisions. This forced labour was used to generate wealth that was enjoyed by the elites or sent abroad, rather than invested in national infrastructure (Klein 2003). The traumatic depth of this experience has led James Dunkerley $(2007,135)$ to refer to the resulting suspicion and paranoia experienced by many Bolivians as "Potosí syndrome;" that is, a fear that outsiders, particularly those from the United States, will exploit their resources and labour. The weight of this historical memory of exploitation does account for some of the scepticism harboured by people in Kirkiyawi towards the work of INRA. To them, various arms of the current government are also seen as "outsiders," and not markedly different from the foreign interests with whom they have regularly colluded.

Thousands left their rural highland villages during the seventeenth century in order to avoid the mita and other tax burdens on those with originario status (Saignes 1995). In new communities, these migrants were awarded the legal personality of forasteros (outsiders, not living in community with their original kin group) and as such were spared the mita taxation. Sánchez-Albornóz (1978, 27 in Lehmann 1982, 21) shows that in 1683, forty-five per cent of adult male indians in what is now Bolivia were forasteros, suggesting extensive rural-to-rural migration as people left behind their own ayllus and the then heavy burden of originario status in order to continue a farming life with less fiscal pressure as a forastero in a new ayllu.

Along with taxation and forced re-settlements, the establishment of encomiendas and haciendas also worked to create tributary relationships rigged against the rural poor. Encomiendas were populated areas bestowed on the elite. Not only did the communities of the encomienda have to pay tribute to the grantee, but they would carve up the land of ethnic groups, having serious effects on local notions of territory and social structures (Larson 1998, 34). Owners demanded tribute in forms of labour, as well as goods and money, forcing the commodification of ayllu produce. The seizing of ayllu lands and founding of haciendas during the end of the sixteenth century also disenfranchised the ayllu populations and created a class of landless labourers who were bound through pongueaje (servitude) to the hacienda lands and homestead. ${ }^{13}$

\footnotetext{
${ }^{13}$ Although many of the hacienda workers were yanacondas, a group that had been landless previous to the Spanish
} 
The second boom of haciendas in the late nineteenth century and early twentieth century claimed a great expanse of ayllu land which had up until then remained in the hands of Aymara and Quechua-speaking groups. In 1880 ayllus still held half the land and half the population in the highlands, but by 1930 they were reduced to a third of both (Klein 2003, 147). Regions were variably affected by this expansion, depending on their geographic location, which impinged upon ease of access, fertility of the land, and level of local ayllu resistance. A number of regions managed to avoid incorporation, including most of ayllu Kirkiyawi, and much of the neighbouring department of Potosí. However, two low-lying areas of ayllu Kirkiyawi, Comuna and Challoma, became hacienda lands, thus costing the ayllu crucial valley lands.

After the fifteen-year campaign by Simón Bolívar and Antonio José de Sucre to liberate the South American continent, Bolivia gained its independence from the Spanish crown in 1825. Although the liberal republican governments that followed espoused a desire to transform society in line with the ideals of the French and American revolution, and the broader Enlightenment ethos of equality and freedom, they concluded that it would be a financially unwise decision to end the legal slavery, so instead extended it, through amongst other things the expansion of the haciendas (Platt 1987). Thus, colonial and racial divisions persisted through the republican years (Larson 2004, 16). While the "two republics" of the Spanish and the indians, were in theory conceptualised as divided by race, Harris argues that the definition over who was indian was often based in their economic activity, the very definition of indian was not only a person of indigenous descent, but also one who did not participate in markets, but rather paid tribute (1995a). These historical categorisations feed into present day motivations regarding participation or non-participation in state projects. Although the native Andean population was in fact highly active in the markets, the association of paying tax with being part of an exploited and powerless class contributes to a strong desire to avoid future fiscal entrapment.

A shift in the tribute system finally came about in the late nineteenth century; though this was not a result of an ideological decision, but rather an outcome of a turn in economic events. The ruling sectors of the early republican period had been dependent on the stability of indian tribute; until the 1850s this made up twenty-six to fifty-two per cent of government revenue (Platt 1987). It was not until the economy picked up - mainly due to guano (accumulated excrement of seabirds and seals) exports and later the rise in the global price of silver - that a new space was freed up where the "indian problem", the perceived need to abolish indian culture and habits, could be tackled more aggressively. The state set out to civilise and socially integrate indians by dissolving the "two republics" at the end of the century. A first step in this process was to entice indians to engage in commerce. Accordingly, under the Decree of the 20th of March 1866, the dictator Mariano Melgarejo began to auction off ayllu land. After decades of onerous tax burdens to protect their lands, the ayllus were now having this very land sold from under their feet. The government of President Tomás Frías continued the trend with the 1874 Disentailment Act, which legally dissolved indian communities and instituted a single universal property tax law (Platt 1984; Larson 2005). The law forcibly created private land deeds for indian communities in order to 
encourage market participation through the transformation of these indians into property holding yeoman farmers (Lazar 2008, 15) and force assimilation with the aim of erasing ethnic difference (Jackson and Warren 2005). As Anthropologist Tristan Platt has argued in his seminal work, Estado Boliviano y Ayllu Andino. Tierra y Tributo en el Norte de Potosi, this new fiscal system was viewed by many ayllus as more exploitative than the previous tax system (1982b). Earlier tribute payments made by ayllus to the colonial state at least ensured a level of self-determination and protection of land. Platt argues that this was seen as a pact of reciprocity whose logic chimed better with ayllu concepts of exchange and governance and where therefore to some degree more acceptable than the 1874 Disentailement Act which aimed to end communal land holding and institute individual taxation. This individualisation also stripped power from those ayllu authorities who had previously acted as tax collectors and thereby shifted power away from the communities. The attack on land and livelihoods continued throughout the twentieth century but fiscal pressure on ayllu lands and its inhabitants lessened as the rural poor engaged predominantly in the informal economy, thus refusing to enter into an individualised fiscal relationship with the state

In the middle of the twentieth century socio-economic and political life changed dramatically in Bolivia: after a three-day battle by miners, workers, various lower class sectors of the city (but very few peasants), the MNR (Movimiento Nacionalista Revolucionario, Revolutionary Nationalist Movement) coup on the $9^{\text {th }}$ of April 1952 marked the Bolivian revolution. The subsequent MNR government brought in universal suffrage and, with the slogan "land to those who work it," the Agrarian Reform of 1953 ended the colonial feudal agricultural system. Former serfs were free to move, but as the promised land often never materialised, the 1950s and 1960s saw a large wave of rural to urban migration (Albó, Greaves and Sandoval 1981; Lazar 2008; Paerregaard 1997).

The post-revolutionary period saw the complete demolition of the oligarchic state, a move to a more state-controlled economy and the sponsorship of the federation of trade unions, Central Obrera Boliviana (COB). The $\mathrm{COB}$ has now represented a large population of heterogeneous workers in Bolivia for over six decades. The peasant union, CSUTCB (Confederación Sindical Única de Trabajadores Campesinos de Bolivia), established in 1979, has also deeply penetrated rural areas and become a key structure through which local politics are organised. The powers of the unions have waxed and waned since their establishment. In particular, the 1980s and 1990s saw a decline in political leverage of the labour movements and instead "indigenous identity" became a highly effective concept through which to claim rights and power (Yashar 1999). Apart from the years when they were closely associated with the MNR governments, they have generally been perceived as separate from the state, yet powerful enough to exercise influence over governments. Juan Claudio Lechín has argued that the Miners Federation (Federación Sindical de Trabajadores Mineros de Bolivia, FSTMB) and the COB are "an alternative state with people, mechanisms of representation and government, organised and unified leadership structure, and a territory superimposed over that of official structures" (2003, 14 cited in Lazar 2008, 248). Following Lechín, I believe that the unions are perceived as a powerful alternative structure to the state that can offer representation, resources and military might. Crucially, unions create a body 
politic larger than the local ayllu. This is a more centralised type if 'citizenship' and therefore akin to national citizenship. Whilst the unions are seen by some indigenous leaders and intellectuals as being in direct conflict with ayllu values (see for instance Rivera Cusicanqui 1990), I would argue, in line with Albro, that indigenous experience and political subjectivity goes beyond the ayllu and "we should recognise the agency of a plural-popular subject" $(2006,396)$. The power and unique position of the unions may be key to the packaging and therefore ultimate success of fiscal expansion in Bolivia.

In 1981, following hyperinflation, budget deficit and debt crisis, Bolivia became the first nation to default on the servicing of its international debt. In 1985, President Victor Paz Estenssoro enacted austerity measures through his "New Economic Policy" (NEP Decree 21060), in response to demands by the International Monetary Fund and the World Bank, and based on the economic rationale of Jeffrey Sachs (Van Vleet 2008). On the street, the NEP Decree 21060 became known as the Ley Maldita (accursed law), as the policies removed price control and subsidies on agricultural products, petroleum and gas; froze wages; privatised state enterprises, including the petrol company (Yacimientos Petroliferos Fiscales Bolivianos, YPFB); and shut down state mining, dismissing a majority of the workers. NEP supplanted social rights with civil and political rights. Inequalities increased and the standard of living dropped (Assies 2000; Postero 2005; Sieder 2000; Yashar 2005).

Amid the privatisation of the oil and gas industries, shares were auctioned to the private sector, a process that turned control of YPFB's major assets over to private companies. The winners of these auctions, including Enron, Shell and Repsol YPF, were not asked to pay for their shares, instead they simply committed themselves to investing an amount at least equal to the sale "price" over a period of seven years, an archetypal case of neoliberal governments giving away state assets (Bonifaz and Lefebvre 2014). Rather than attempting to raise taxes on the immensely profitable hydrocarbons industry that was by then dominated by foreign corporations, the government announced it would create an income tax (the so-called "impuestazo" of 2003) despite prevailing low wages, high unemployment, and high levels of poverty. This time it was the urban middle classes who were placed under great fiscal pressure instead of rural indigenous groups, but the whole population once again had to watch as wealth left the country and public good was ignored. The situation escalated into massive demonstrations in what has become known as Febrero Negro (Black February), resulting in over thirty dead (civilians, military and police). Febrero Negro was one of the events leading up to the final ousting of the incumbent president Sánchez de Lozada in October of 2003 and the eventual election of Evo Morales.

In May of 2006, five months into his presidency, Evo Morales nationalized the hydrocarbons sector, re-founding the state company YPFB through a purchase of majority shares in the privatised enterprises and thus reclaimed public ownership over the country's gas and oil resources. The nationalization decree also forced foreign oil companies to renegotiate contracts with the new administration. This has resulted in increased revenues to the central government that in 2011 were worth sixteen percent of total hydrocarbon revenues. The nationalization process has arguably been less successful than promised, due partly to the binding nature of existing export contracts, 
with for instance Brazil, and the stubborn effects of Bolivia's previous neoliberal policies (Kaup 2010). Many indigenous activist and academics, claim the case is worse than this, not only are the reforms not able to have the impact they intended but this new "progressive" extractivism is much like old extractivism - destroying the environment, generating intense social conflict, and eroding indigenous and citizen rights (Gustafson 2013:1). Aymara activist and academic Silvia Rivera Cusicanqui argues that the MAS is virtually a replica of the neocolonialist development project of the past, allied with a military virtually unchanged from its own past of illicit activities and an antidemocratic Cold War mentality, and running a government amid a growing climate of impunity.... a "revolutionary parody" (Rivera Cusicanqui 2012). Despite this, as mentioned previously, it remains true that Bolivia's population are fiercely aware that the income from the hydrocarbon sector has been used to fund state benefits. This shift from a partnership of corrupt governments and foreign interests who extract wealth to a representative government and national investment which has resulted in lower poverty rates, creates a new context within which the local population can asses the potential good of fiscal expansion.

Historical experience mitigates against the current attempts of fiscal incorporation of the indigenous population in two ways. Firstly, centuries of fiscal exploitation and poor relationship with the state have resulted in a large degree of skepticisms of any state project. Secondly, the previous fiscal structure, with the local cacique being the tax collector and taxes being paid as a community in order to protect land, means the new structure of individual to state is unfamiliar and therefore approached with skepticism. In addition, the culture of direct and local exchange in the ayllu is an awkward fit with national taxation. The place of ayllu culture is crucial, for even if what is seen as core and 'positive' characteristics of ayllu life may be more fantasy on behalf of indigenous activists then a reflection of everyday life in the ayllu, they constitute a valued part of a vision of a potential future and better Bolivia held by many indigenous people. However, while indigenous groups are apprehensive of full inclusion in the Bolivian nation, they have for many decades been committed members of other structures which do spread beyond the community boarders, that of the unions. Not only have the unions been key players in rural local politics for several decades now, the indigenous population are also accustomed to making financial contributions to them. For instance, the informal spaces of urban markets, where many rural indigenous people make a seasonal living, are often regulated by cooperatives and unions who may demand fees from their members. So while those working within these markets rarely participate in national taxation they are accustomed to making payments to a larger organization, who in turn provide infrastructure and a level of social security. This demonstrates the ability of the non-taxpaying population to imagine and believe in the benefits of larger collectives. I have argued that the union model, paired with the anti-establishment sentiment that Morales managed to claim, at least at the beginning of his presidency, could hold the key to fiscal expansion.

Conclusion: Making Taxation a Non-State Project 
In ayllu Kirkiyawi, the delayed expansion of electricity infrastructure was angrily described as a failure on the part of local and departmental government and the corruption inherent in the system. Morales, meanwhile, was not seen to be at fault. On the contrary, Evo Morales is fetishised by the rural poor (Goudsmit 2006). The dark-skinned President with his peasant background and passionate rhetoric is a symbol that leaves no poor Bolivian untouched: "Es uno de nosotros" (He is one of us); "Conoce cómo sufrimos" (He knows how we suffer), are claims that I heard countless times in Kirkiyawi.

While the state increasingly casts taxation as a moral good, suspicion and ambivalence remains firm amongst the rural population and the informally employed. As the story of Kirkiyawi receiving their ayllu title and the reticent kuraj tata who feared this was a potential first step on a road back to fiscal exploitation, at the beginning of the article, illustrates, there exists a deep-seated anxiety amongst most indigenous people towards any state project.

Scepticism of state structures and institutions, such as the Tax Office, has during most of MAS' term, sat alongside a continued devotion to their President Evo Morales. This is because the "long arms" of the state are often viewed as disconnected from the MAS government and its leader. And while many voice dissatisfaction with certain policies or undelivered promises, no one would consider not voting for "nuestro tata presidente" (our father and president).

The main barrier to fiscal engagement is the state itself as it is profoundly tied to a historical memory of fiscal exploitation. While Morales has succeeded in being perceived as non-state, nonestablishment, and is instead considered a true representative of the people, state institutions, like the Tax Office, remain steeped in association with repression and corruption. Overcoming this is the primary challenge of the Tax Office. In addition to trust in Evo Morales, the government could capitalise on the existing structures and willingness to pay dues to unions and cooperatives. As outlined in this article, these organisations have managed to create a sense of membership, obligation and system of exchange. For the new Bolivia to survive and MAS to continue as a credible government, they need to bring about full fiscal inclusion of the whole country, ensuring that all Bolivians have a vested interest in the state. They now have to battle to convince the population that their vision of a pluri-cultural Bolivia is one worth investing in. Fully incorporating the indigenous citizen, who has been placed centre stage of the new Bolivia, is crucial to the continuity of the current nation-making project.

\section{References}

Abercrombie, Thomas. 1991. "To be Indian, to be Bolivian: "Ethnic" and "National" Discourses of Identity." In Nation-States and Indians in Latin America, (eds) G. Urban and J. Sherzer, 95-130. Austin: University of Texas Press.

Albó, Xavier, Thomas Greaves, and Godofredo Sandoval. 1981. Chukíyawu: La Cara Aymara de La Paz. Vol 1. El Paso a la Ciudad. La Paz: CIPCA.

Albro Robert. 2006. "Bolivia"s "Evo phenomenon": From identity to what?" Journal of Latin American Anthropology 11(2): 408-428. 
Albro Robert. 2005. "The Indigenous in the Plural in Bolivian Oppositional Politics." Bulletin of Latin American Research. 24(4): 433-453.

Arnold, Denise with Juan de Dios Yapita. 2006. The Metamorphosis of Heads, Textual Struggles, Education, and Land in the Andes. Pittsburgh: Pittsburgh University Press.

Arnold, Denise. 1988. Matrilineal Practice in a Patrilineal Setting: Rituals and Metaphors of Kinship in an Andean Ayllu. University College London, University of London: Thesis.

Assies, Willem. 2000. "Indigenous Peoples and Reform of the state in Latin America." In The Challenge of Diversity, Indigenous people and Reform of the State in Latin America, W. Assies, G. Van der Haar and A. Hoekema, eds, 3-22. Amsterdam: THELA THESIS.

Bebbington, Anthony. 2009. "The New Extraction: Rewriting the Political Ecology of the Andes." NACLA Report on the Americas vol 42:5: 12-20.

Bonifaz, Jeanette and Stephan Lefebvre. 2014. Lessons from Bolivia: re-nationalising the hydrocarbon industry. Open Democracy UK, November 24.

Bouysse-Cassagne, Thérèse, Olivia Harris and Tristan Platt. 2004. Qaraqara-Charka: Mallku, Inka y Rey en la "Provincia de Charcas" (siglos XV-XVII);Historia Antropológica de una Confederación Aymara. La Paz: Ediciones Plural.

Canessa, Andrew. 2006. "Todos Somos Indígenas: Towards a New Language of National Political Identity." Bulletin of Latin American Research. 25(2): 241-263.

Canessa, Andrew. (ed) 2005. Natives Making Nation: Gender, Indigeneity, and the State in the Andes. Tucson: The University of Arizona Press.

Cañedo-Argüelles Fabrega, Teresa and Gutiérrez Flores, Juan. 2005. La Visita de Juan Gutiérrez Flores Al Colesuyo y Pleitos Por Los Cacicazgos de Torata y Moquegua. Lima: Pontificia Universidad Católica del Perú Fondo Editorial.

Celestino, Olinda and Alberd Meyers. 1981. Las Cofradías en el Perú: Región Central. Frankfurt: Vervuert.

Christian, William. 1981. Local Religion in Sixteenth-Century Spain. Princeton: Princeton University Press.

Dunkerley, James. 2007. "Evo Morales, the "Two Bolivias" and the Third Bolivian Revolution." Journal of Latin American Studies 39(1):133-166.

Espinoza Soriano, Valdemar. 1997. "Caracara: Etnohistoria de una nación Aymara." Nueva Sintesis. Revista de Humanidades 5 (IV): 25-92.

Fabricant, Nicole and Nancy Postero. 2015. "Sacrificing Indigenous Bodies and Lands: The Political-Economic History of Lowland Bolivia in Light of the Recent TIPNIS Debate." The Journal of Latin American and Caribbean Anthropology. Vol 20:3:452-474.

Goodale, Mark. 2001. A Complex Universe in Motion: Rights, Obligations and Rural-Legal Intellectuality in the Bolivian Andes, PhD. University of Wisconsin-Madison.

Goudsmit, Into. 2006. So far from God, so near the Mountains: Peasant Deference to the State and Landlords in the Bolivian Andes, PhD. Goldsmiths College, University of London.

Gudynas, Eduardo. 2011. "Buen Vivir: Today's Tomorrow." Development 54(4):441-447.

Gustafson, Bret. 2013. "Amid Gas, Where Is the Revolution." NACLA Report on the Americas vol 46(1): 61-66.

Harris, Olivia. 2000. To Make the Earth Bear Fruit. London: ILAS.

Harris, Olivia. 1995a. "Ethnic Identities and Market Relations: Indian and Mestizos in the Andes." In Ethnicity, Markets and Migration in the Andes O. Harris and B. Larson, eds, 351-390. Durham \& London: Duke University Press.

Harris, Olivia. 1995b. Knowing the Past: Plural Identities and the Antimonies of Loss in 
Highland Bolivia. In Counterworks; Managing the Diversity of Knowledge (ed) R. Fardon, 105-123. London: Routledge.

Izko, Xavier. 1992. La Doble Frontera. La Paz: Hisbol.

Jackson, Jean and Kay Warren. 2005. "Indigenous Movements in Latin America, 1992-2004:

Controversies, Ironies, New Directions." Annual Review of Anthropology 34:549-573.

Kaup, Brent. 2010. "A Neoliberal Nationalization: The Constraints on Natural Gas-Led

Development in Bolivia." Latin American Perspectives 37:3:123-138

Klein, Herbert. 2003. A Concise History of Bolivia. Cambridge: Cambridge University Press.

Larson, Brooke. 2005. "Capturing Indian Bodies, Hearths and Minds: the Gendered Politics of Rural School Reform in Bolivia, 1920s-1940s.” In Natives Making Nation: Gender, Indigeneity, and the State in the Andes. A. Canessa, ed, 35-59. Tucson: The University of Arizona Press.

Larson, Brooke. 2004. Trials of Nation Making. Liberalism, Race, and Ethnicity in the Andes, 1810-1910. Cambridge: Cambridge University Press.

Larson, Brooke. 1995. "Andean Communities, Political Cultures, and Markets: The Changing Contours of a Field." In Ethnicity, Markets and Migration in the Andes O. Harris and B. Larson, eds, 5-54. Durham \& London: Duke University Press.

Larson, Brooke. 1998. Colonialism and Agrarian Transformation in Bolivia, Cochabamba 15501900. Princeton: Princeton University Press.

Lazar, Sian. 2008. El Alto, Rebel City: Self and Citizenship in Andean Bolivia. Durham: Duke University Press.

Lehmann, David. 1982. Ecology and Exchange in the Andes. Cambridge: Cambridge University Press.

McNeish, John. 2001. Pueblo Chico, Infierno Grande: Globalisation and the Politics of Participation in Highland Bolivia, PhD. London: Goldsmiths College.

Mercedes del Río, María de las. 2005. Etnicidad, territorialidad y colonialismo en los Andes: tradición y cambio entre los soras de los siglos XVI y XVII. La Paz: Instituto de Estudios Bolivianos.

Molinié Fioravanti, Antoinette. 1986. "The Andean Community Today.” In Anthropological History of Andean Polities. J. Murra, J. Revel and N. Wachtel, eds, 342-358. Cambridge: Cambridge University Press.

Murra, John. 1978 La Organización Económica del Estado Inka. Mexico, DF: Siglo XXI.

Murra, John, Nathan Wachtel and Jacques Revel. 1986. "Introduction.” In Anthropological History of Andean Polities. J. Murra, J. Revel and N. Wachtel eds, 1-8. Cambridge: Cambridge University Press.

Paerregaard, Karsten. 1997. Linking Separate Worlds. Oxford: Berg.

Platt, Tristan. 1987. "The Andean Experience of Bolivian Liberalism.1825-1900: Roots of Rebellion in 19th-century Chayanta (Potosí)." In Resistance, Rebellion and Consciousness in the Andean Peasant World, 18th to 20th Centuries. S. Stern, ed, 280327. Wisconsin: University of Wisconsin Press.

Platt, Tristan. 1984. "Liberalism and Ethnocide in the Southern Andes." History Workshop Journal 17(1):3-18.

Platt, Tristan. 1982a. "The Role of the Andean Ayllu in the Reproduction of the Petty Commodity Regime of Norte de Potosí (Bolivia)." In Ecology and Exchange in the Andes. D. Lehmann, ed, 27-69. Cambridge: Cambridge University Press.

Platt, Tristan. 1982b Estado Boliviano y Ayllu Andino. Tierra y Tributo en el Norte de Potosi. 
Lima: Instituto de Estudios Peruanos.

Postero, Nancy. 2005. "Indigenous Responses to Neoliberalism: A Look at the Bolivian Uprising of 2003." POLAR: Political and Legal Anthropology Review 28(1):73-92.

Rasnake, Roger. 1988. Domination and Cultural Resistance; Authority and Power among an Andean people. Durham: Duke University press.

Rivera Cusicanqui, Silvia. "Del MNR a Evo Morales: disyunciones del estado colonial." Bolpress, January 31.

Rivera Cusicanqui, Silvia. 1990. "Liberal Democracy and Ayllu Democracy in Bolivia." Journal of Development Studies 26(4): 97-121.

Rivera Cusicanqui, Silvia. 1987. Oppressed but not Defeated. Geneva: United Nations Research.

Rostworowski, Maria. 1978. Senorios Indigenas de Lima y Canta. Lima: Instituto de Estudios Peruanos.

Saignes, Thierry. 1995. "'Indian Migration and Social Change in Seventeenth Century Charcas." In Ethnicity, Markets and Migration in the Andes O. Harris and B. Larson, eds, 167-195. Durham: Duke University Press.

Sánchez, Rodrigo. 1982. "The Andean Economic System and Capitalism.” In Ecology and Exchange in the Andes. D. Lehmann, ed, 157-190. Cambridge: Cambridge University Press.

Sieder, Rachel, ed. 2002. Multiculturalism in Latin America, Indigenous Rights, Diversity and Democracy. New York: Palgrave Macmillan.

Sieder, Rachel. 2000. "Paz, Progreso, Justicia y Honradez: Law and Citizenship in Alta Verapaz During the Regime of Jorge Ubico." Bulletin of Latin American Research 19(3):283-302.

Sikor, T. 2006. "Land as Asset, Land as Liability" in Changing Properties of Property. F von, K von Benda-Beckmann, and M Wiber, eds, 106-125. New York, Oxford: Berghahn Books.

Silverblatt, Irene. 1988. "Political Memories and Colonizing Symbls: Santiago and the Mountain Gods of Colonial Peru." In Rethinking History and Myth: Indigenous South American Perspectives on the Past, Jonathan D. Hill (ed), 174-194. Urbana: University of Illinois Press.

Soux, María Luisa. 2010. El complejo proceso hacia la independencia de Charcas (1808-1826): Guerra, ciudadanía, conflictos locales y participación indígena en Oruro. La Paz: Plural editores.

Spedding, Alison. 2010. ““'Suma qamaña” Kamsañ muni?(Que quiere decir “vivir bien”?” Féy Pueblo (La Paz) no20:Julio: 4-39.

Stern, Steve 1982. Peru's Indian Peoples and the Challenge of Spanish Conquest. Madison: University of Wisconsin Press.

Thomson, Sinclair. 2002. We alone will rule: Native Andean Politics in the Age of Insurgency. Madison: The University of Wisconsin Press.

Van Vleet, Krista. 2009. Performing Kinship: Narrative, Gender and Intimacies of Power in the Andes. Austin: University of Texas Press.

Verdery, K. 2004. "The Obligations of Ownership: Restoring Rights to Land in Post-socialist Transylvania" in Property in Question, Value Transformation in the Global Economy (eds) C Humphrey and K Verdery, eds, 139-160. Oxford, New York: Berg.

Weismantel, Mary. 2001. Cholas and Pishtacos: Stories of Race and Sex in the Andes. Chicago: Chicago University Press.

Yashar, Deborah. 2005. Contesting Citizenship in Latin America, The rise of indigenous Movements and the Post-liberal Challenge. Cambridge: Cambridge University Press. 
Yashar, Deborah. 1999. "Democracy, Indigenous Movements, and the Post-Liberal Challenge in Latin America." World Politics 52 (1): 76-104.

Atlas de Los Ayllus Sura y Qurpa Kirkiyawi. 2002. Cochabamba: Programa de Desarollo de Los Valles de arque and Tapacari (PRODEVAT). 